\title{
Conceptions of the Future of Contemporary Civilization
}

\author{
Nikoleta Mihaleva \\ Department of Social Sciences and Humanities, Faculty of Management, University of Economics, Varna, Bulgaria \\ Email address: \\ neti_mihaleva@mail.bg

\section{To cite this article:} \\ Nikoleta Mihaleva. Conceptions of the Future of Contemporary Civilization. International Journal of Philosophy. \\ Vol. 7, No. 2, 2019, pp. 62-65. doi: 10.11648/j.ijp.20190702.13
}

Received: March 25, 2019; Accepted: May 23, 2019; Published: June 11, 2019

\begin{abstract}
The article discusses the future of European civilization on the basis of the theoretical views of O. Spengler ("cultural ages" and "fate"), A. Toynbee ("soul" and "Prometheus impulse"), N. Berdyaev ("barbarism", "culture", "civilization and religious transformation"), as well as certain representatives of postmodernism, who clearly indicate the crisis of the cultural values of our contemporaneity: J. Derrida, J. F. Lyotard, M. Foucault. There is made an attempt at formulating the dominant values of the western European civilization, namely the dominant values that have crystallized from Antiquity to modern dimensions of modern man such as autonomy, self-determination of the individual, and the idea of an active-creative beginning and the possibility for their transformation following the example of eastern cultures. Using the historical and analytical method, the study outlines critical global issues (ecological, anthropological, educational, etc.), which require serious reconsideration of the value priorities, such as the ideal of the transformation of nature. Special attention is paid to certain ideals and principles of man's attitude to nature and to themselves, coming from the Eastern cultural traditions. The main conclusion that can be drawn is that only the dialogue between the West culture and the East culture would be the salvation of our civilization.
\end{abstract}

Keywords: Culture, Civilization, Cultural Ages, Crisis of Values, Postmodernism

\section{Introduction}

Why do we get so excited about the issue of the future of our European civilization? Probably because few are the things that interest a person as much as their fate (fatum) something which brings too many unknowns. But - however limited freedom is in the history of mankind - there are two real historical options: decline or advancement. Therefore, always, on the verge of historical transitions, in ages of crisis, in times of change of centuries and millennia, there arises the question of the future and its direction, its vision (O. Spengler, The Decline of the West; F. Fukuyama, The end of History and the Last Man; A. Camus, The Human Crisis; S. Huntington, The Clash of Civilizations; P. Buchanan, The Death of the West, etc.). An analysis of the concepts of civilization development by O. Spengler, A. Toinby, N. Berdjaev, A. Kamyou affirms the adherence of the spiritual principle as an integrative center of European culture, introducing an excessive assessment of the results of global change.

\section{Concepts of Civilization Development}

I will start the exposition in this article by examining the etymology of the concept of "civilization". The term civilisatio is a new coinage based on the Latin adjective civilis (civil, polite) and the noun civilitas (politeness). In the French language this term is used for the notion of culture, but in English, Russian and particularly in the German language there is the tendency to view the two terms (culture and civilization) as close in meaning, but not identical. The difference arises from the fact that the concept of civilization is sometimes limited only to the understanding of advanced or developed cultures. Some authors consider civilization proceeding from its etymology - as a culture of societies, characterized by the development of towns and cities, whereas others use it mainly to refer to cultures having their own writing systems. [1] The difference between culture and civilization, particularly in the German linguistic practice, consists in the notion that culture is the expression and the success of the will to self-development of a certain people or a certain individual, whereas civilization is the totality of 
technological achievements and the advancement connected with the latter. The dynamics between culture and civilization is borne by the fact that they are "legitimized" in a different manner: culture has to do with values, the spiritual, the creative, the individual, whereas civilization has to do with the utilitarian, the technological, the collective, the material. The German philosopher H. Marcuse (1898-1979) criticizes modern civilization for the rising scale of alienation, manipulation of consciousness and the emergence of the "one-dimensional man" of mass culture (homo faber) [2]. $\mathrm{He}$ defines culture as a "spiritual celebration", in contrast to civilization, which is a "despondent routine".

The outcome of the conflict between culture and civilization for Europe and the world is most dramatically (and pessimistically) indicated in the book by $O$. Spengler (1880-1936) The Decline of the West [3]. The German philosopher describes world cultures as living organisms, as sort of collective souls, which pass through different cultural ages: birth, bloom, aging and death. They have a unique and matchless fate and produce results in the form of arts, philosophy and knowledge. Spengler lists seven cultures, four of which are past: the Egyptian, the Chinese, the Indian, the Near East, one present - the West European-North American, and a future one - the Russian-Siberian. The "life" of each one of those can be viewed as consisting of two periods: a period of youth, called culture and a period of old age - civilization. During the first period the energy of the society is directed inwards, this is the age of spiritual achievement, whereas during the second period it is directed outwards, development is extensive, this is an age of mental, rational achievement. [4] Thus civilization turns out to be the inevitable fate of culture. Studying the history of West European society Spengler draws the conclusion that culture has already been exhausted and that it has entered the age of civilization. That is why he characterizes it as "The decline of Antiquity", making an analogy with the fate of the Roman world.

The British historian and anthropologist A. Toynbee (18891975) analyzes world history and also introduces the concepts of "fate" and "soul" [5]. In the anatomy of the public historical process he considers a unifying idea: man is at the root of all creations, cataclysms and catastrophes. "The engines" of the historical life of the world are those personalities, whom Toynbee calls "creative", and who have gone beyond the times with their ideas and their activity. It is with them that all triumphs and misfortunes in history are connected. A. Toynbee traces out 21 human civilizations, which were in a period of growth, 13 of them are extinct (e.g. the Celtic, the Scandinavian), 7 have stopped their development (the Eskimo, the Spartan, the Polynesian, etc.), and the last one - our civilization, is already past its zenith, because it has lost its "Promethean" impulse. In the modern West European civilization there are no longer creative personalities, but only automatic executors, a mass. [6] In a number of places in his multivolume A Study of History he expresses the assumption that perhaps "The Door of Death", through which there have passed many flourishing civilizations, is the erosion of morality and the lack of positive change in the nature of man. However, unlike the upholders of the idea of "cultural decline", Toynbee sees no hopelessness in the human effort on the way towards advancement, but rather draws the optimistic idea of creating a universal civilization in the near future, based on spirituality.

There is no doubt that civilization is a real threat, a real crisis of culture, but culture does not perish. The great Russian philosopher N. Berdyaev (1874-1948) - although he shares the view of Spengler - argues that the decline of culture does not necessarily mean that it is condemned and is dying [7]. According to him it is eternal and mankind passes through four stages in its development: barbarism, culture, civilization and religious transfiguration. In his study The Will to Live and the Will for Culture Berdyaev develops the idea that culture, which is always aristocratic, ceases to be a higher spiritual value, rather, in it there gets the upper hand the will to live. Culture is defined as "the great failure of life". The civilization starts to bear the spirit of the New Times, and in it a special place is reserved for technology, which achieves the great practical results. Thus culture loses its most essential quality: its self-worth. In the age of civilization it disintegrates, gets fragmented, "diffracts".

In essence the presented thoughts of the authors are an expression of the doubts in the idea of progress, in the possibility of resolving contradictions in world history. [8] Without having this extreme character, but clearly showing the crisis of the cultural values of our contemporaneity, is also the criticism of the representatives of postmodernism: $J$. Derrida, J. F. Lyotard, M. Foucault, etc. Postmodernism is a movement which opposes the world order as such, and the values which create it. It is an effort to understand the global state of civilization, the total aggregate of cultural attitudes and philosophical trends during the last decades. In that sense postmodernism is not so much a new doctrine, as it is a diagnosis of the times. It is an expression of the selfreflection of a cultural awareness which problematizes itself, because it has lost its historical identity. It is no accident that Lyotard defines postmodernism as a type of sensation, as speculation, and the state of modern culture he describes in a single word - eclecticism [9]. In the quest to identify itself, postmodernism is confronted with its own mosaic nature, its boundlessness. Because of that it gives up the idea of assigning a unified ideal or meaning to contemporaneity, but rather presents it as a loose sum total of trends which form a new cultural matrix.

Yet how should we characterize the general situation with the values of European culture in the 20th century? Can we talk about a crisis and destruction of values, or about their successive transformation? In the studies on this issue there are supported both views. If we accept the proposition of an existing crisis of values, this will entail a precedence of the destructive processes, which, along with the old values also destroy a large number of positive values. So the situation today is approaching anomie, i.e. the painful absence of new values. But the value crisis is far from signifying destruction 
of values. This is because, as with certain diseases, "the crisis", although dangerous, can lead to either death or recovery. So the crisis of values does not preclude their transformation, rather it signals the development of new value systems which are in conflict with the old ones.

The symptoms of the crisis of European values are revealed by the French existentialist Albert Camus (19131960) in his text given in a lecture before American students in New York in 1948, entitled The Human Crisis. The contemporary crisis, according to him, is manifested by the fact that man is no longer sure of his future. He has lost the freedom of the mind, without which none of the issues facing mankind can be resolved. Camus' judgement on the fate of European values is frightful - there has been lost the spiritual principle, which has always united contemporaries in the name of values that are common to all. "Because, if man does not believe in anything," writes Camus, "if nothing makes sense and we are unable to find value in anything, then everything is allowed and nothing really matters. Then there is neither good, nor evil ..." [10]. In that sense an underlying principle in the entire European history is spirituality. It "germinates" as far back as in Ancient Greece as a new understanding of life - unified, wholesome, led by reason, comprehensive and universal, in the context of the universum. And despite the modifications it has gone through, the spiritual principle remains an integrating centre of European culture.

The European civilization is of great historical duration and passes through complex and significant periods: of three economic formations and a global religion - Christianity (which sort of "deposes" the Graeco-Pagan religion that precedes it). These periods possess their own specific sociocultural forms, values and civilization achievements, their own central ideas and spiritual dimensions. Thus the global Euro-civilization principle of spirituality (and its corresponding values) is fulfilled through historical zigzags, some of which realize it more fully, while others - more onesidedly. But its extraordinary significance consists in the constitution of the European historical subject, the European man. The dominant values, having crystallized in the time from Antiquity until the contemporary dimensions of modern man, are autonomy, self-determination of the individual and the idea of the active-creative beginning. What is more, this is the clear awareness of the individual as inextricably bound up with his right to possess and inherit the material and spiritual benefits of his labour. This form of European spirit, and perhaps - to put it boldly - universal spirit, views man as a theorist and practitioner, as an inventor and implementer, as someone who gets to know in action and acts knowingly.

The famous Spanish philosopher José Ortega y Gasset writes: "The Spanish, the Germans, the English, the French are and will be as different as one is inclined to view them. But they have the same psychic structure and above all are oriented towards the same nature. If today we strike a balance of our entire spiritual heritage: theories and norms, desires and hopes, we will find that most of them originate not from their respective homeland, but rather from the common European foundation. In every one of us the European man weighs down much more than the German, the Spaniard, the Frenchman ..." [11].

In the majority of culturological opinions, however, the spiritual principle referred to above is viewed as peculiar to West European civilization. It is precisely in it that there are organized and integrated the two opposing spiritual elements: "Christian antiquity" and "paganism" as two types of culture that precede it. From the 11th century - right up to the beginning of the 20th century - the western civilization has a huge impact on other civilizations, cultures and societies and exercises its control over them. The main reason for that is its technological advancement and the corresponding dominant values of the latter. However, they also outline the beginning of fateful global problems (environmental, anthropological, educational, etc.), which requires a serious reconsideration of priorities with respect to values [12]. First: In the European technogenic civilization there has been well-established the idea of man as active being, who opposes nature and rules over it. He very nearly comes in this world in order to change, transform, conquer and exploit it, and not at all to simply understand, explain, rationalize and - finally - like a truly rational host to make it cosy. Of course the global crises that have been caused are not just a natural product of modern civilization itself, but mainly the result of the type of mentality and worldview - characteristic of it - which still determine our hedonistic-irresponsible attitude towards Nature and Culture. Second: A characteristic basic value of the technogenic culture is also the understanding of nature as an inorganic world, as a boundless source of materials and resources, from which the human race can draw indefinitely. Third: As a value ideal, the technogenic civilization has affirmed the free individuality, the independent personality that can join various social communities having equal rights with the other citizens. Fourth: A special place and dominant signification is given the value of innovation and advancement based on the priority status of science. Fifth: Last but not least there is the understanding of authority and power, aimed not only at the natural, but also at the social objects.

The intensifying global issues, however, impose the need for a thorough reconsideration of some of the priority values mentioned above, among which the ideal of the transformation (in the sense of "possession", exploitation, destruction) of nature stands out with particular urgency. But the search for new reasons for another type of civilization development, can by no means reverse the attitude for an ever accelerating production of scientific knowledge and its application. If the scientific and technical development has been harmonized only with the western system of values for centuries on end, then the increasing danger of global crises shows that this orientation is not the most appropriate [13]. To that end there are laid special hopes on certain ideals and principles of the attitude of man towards nature and himself, coming from the eastern cultural traditions. For instance, this is the idea of nature as a living organism, the strategy of nonviolence, and above all the restoration of the balance 
between scientific and moral values.

\section{Conclusion}

Our contemporary civilization is responsible for the continuation of the idea of a universal humanism. The great French anthropologist and ethnologist Claude Lévi-Strauss logically raises the question: "What would we leave to the coming generations as evidence of the ups of our civilization, before we, or our successors, have malevolently destroyed it? The purity of the elements, the diversity of living creatures, the gracefulness of nature and the decency of the people!" [14].

It is beyond dispute that in the culture of the future there will occur changes. The trends for change are varied. They are in competition with each other. Some of them may have disastrous consequences. Because of that, it is of utmost importance to reconsider and hand over to the coming generations those cultural universals, which would not lead to the degradation of culture. But it is very difficult to say what exactly the new values must be. [15] For complex developing systems, such as society and culture, the prognoses presume the emergence of a multitude of scenarios. One thing is certainly unacceptable for the scenario of the future - the destruction of humanistic ideals and the loss of morality.

My opinion is that there stands out the need to discuss an extremely topical and important question - the dialogue between the West and the East. It is determined by the growing trends of cultural diversity that are lying at the basis of multiculturalism, by the need for cultural dialogue and culture of dialogue. The more open to dialogue a culture is, the greater number its chances for enrichment and development. Could this be the salvation of our civilization?

\section{References}

[1] Bowden, B. Civilization and Its Consequences. Oxford Handbooks online, 2016.

[2] Markuze, H. Ednoizmerniyat chovek. S. 1997.

[3] Shpengler, O. Zalezat na Zapada. v. I, S., 1994, v. II, 1995.

[4] Weismann, I. Material Progress and Spiritual Superiority: Muslim Brotherhood Conceptions of Civilization., Journal of Civilization Studies 1 (2): 25-42, 2014.

[5] Toynbi, A. Izsledvane na istoriyata. S., 1995.

[6] Zarakol, A. After Defeat: How the East Learned to Live with the West. Cambridge, UK: Cambridge University Press, 2011.

[7] Berdyaev, N. Smisalat na istoriyata. S., 1994.

[8] Tonn, B. E. Philosophical, institutional, and decision making frameworks for meeting obligations to future generations, Futures, Vol. 95, pp. 44-57, 2017.

[9] Liotar, Zh. F. Postmoderni pouki, Sofia: Kritika i humanizam, 2002.

[10] Kamyu, A. Kriza na choveshkoto. Evropeyski ekzistentsialisti. Izd. "Prosveta", S., 1993, p. 37.

[11] Ortega-i-Gaset, H. Chovekat i horata. S., 1999.

[12] Nauka i kultura (Materialy "kruglogo stola"). v: sp. "Voprosy filosofii", 1998, No10, p. 7.

[13] Prigozhin, I., I. Stenzher. Novata vrazka. Metamorfozata na naukata. S., Izd. Nauka i izkustvo, 1989.

[14] Levi-Stros, K. Strukturna antropologia II. Sofia, 1995, p. 369.

[15] Gloor, L. and Mannino, A. The case for suffering-focused ethics, Foundational Research Institute, https://foundationalresearch.org/the-case-for-suffering-focused- ethics, 2016. 